\title{
STRATEGIES FOR RECHRISTIANIZATION. POLITICAL RHETORIC OF THE NORWEGIAN HOME MISSION IN THE 1920's ${ }^{1}$
}

\author{
Arne Bugge AMUNDSEN \\ Department of Cultural Studies, University of Oslo \\ Postbooks 1010, Blindern, N-0315, Oslo, Norway
}

\begin{abstract}
The paper discusses the strategies and the rhetorical elements of the Norwegian Inner Mission during a period of political and cultural conflict - the 1920's and 1930's. Special attention is paid to understanding the ambivalence between premodern values and modern strategies as they were expressed by one of the leaders of one of the inner mission organisations, professor of theology Ole Hallesby (1879-1961). In his thinking, the explicit aim of the inner mission activities was the rechristianization of Norway, the means were actions organised according to the modern society, but the cultural and social ideal was the non-secularized, premodern Norway - as opposed to urban pluralism. Probably, this ambivalence made the inner mission strategy a political failure.

Keywords: pietism, religious organisations, inner mission, national revival, secularization, modernity and premodernity
\end{abstract}

Norway has never been dominated by strong, aggressive free churches. Instead, the Norwegian Lutheran State Church - established in its present shape by the Constitution of 1814 - became the fundament for most strategies in order to explicate religious values, formulate religious protest or secularize the civil society. Even today, most Norwegians belong to the Lutheran State Church. ${ }^{2}$

However, during the 19th century, several autonomous religious organisations were established within the State Church. These organisations for the most part were dominated by different kinds of pietist ideology and puritan models for religious life. Their aims could be multiple, and cover for instance both foreign mission, home mission and social work. A national Foreign Mission Society was established in 1842 , and in 1868 a parallel society aiming at national home mission was organised, the so-called Luther Foundation.

During most of the 19th century, these religious organisations within the State Church were interesting combinations of working strategies and social structures that were both modern and premodern. Evidently, the very fact that the two national

\footnotetext{
${ }^{1}$ This article is based on my paper "Vennene og vekkelsen. Hallesbys signalement av indremisjonskulturen" (1999, in press).

2 There are, unfortunately, very few general presentations of the Norwegian church and religious history in foreign languages. Information of a certain relevance and value for the period described in this article is, however, to be found in GJESSING 1911, Die Kirche von Norwegen 1936, and HASSING 1980 (on Methodism and popular revivals in the 19th century). Certain aspects are also dealt with in THORKILDSEN 1996. A short survey is presented in MOLLAND 1957.
} 


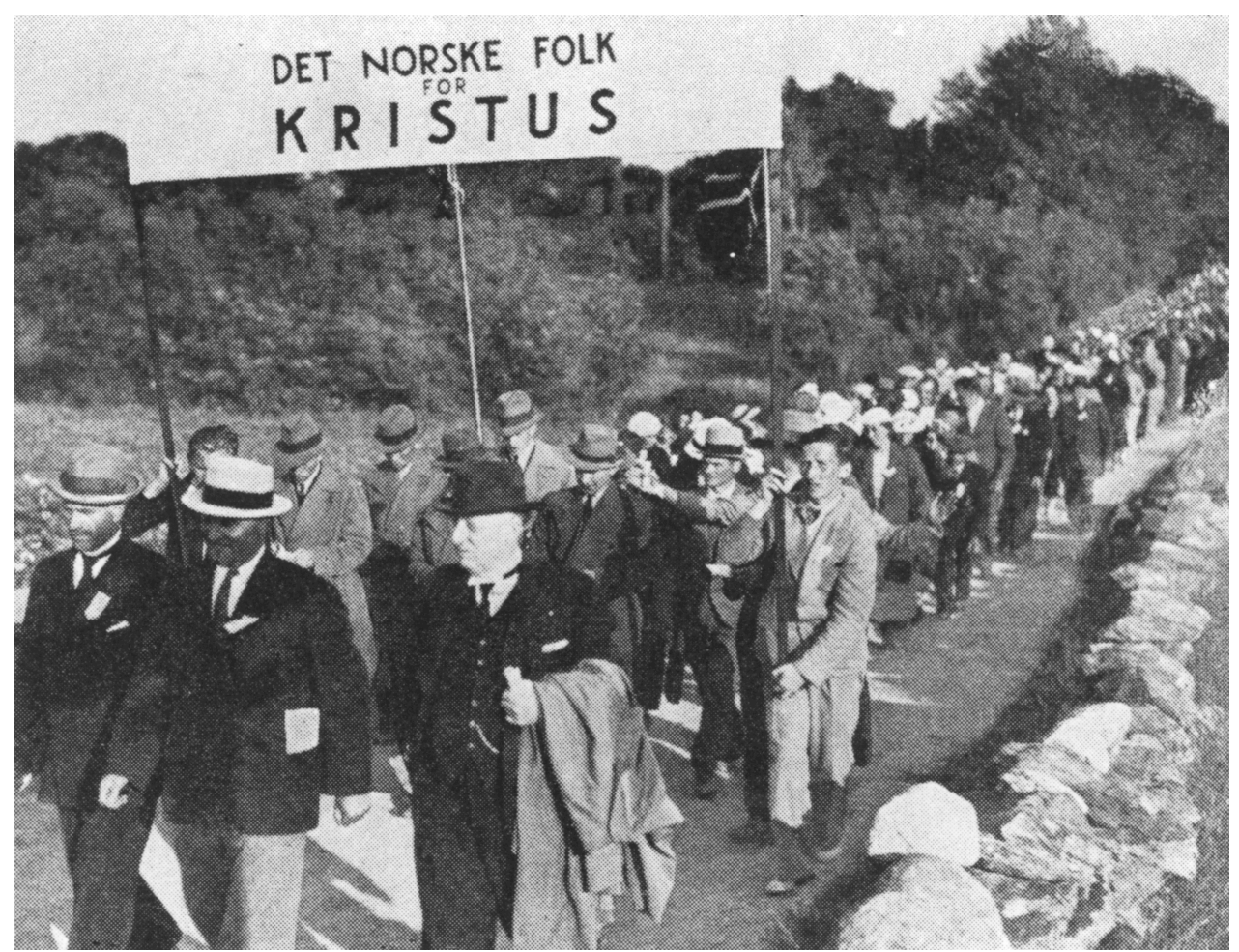

Fig 1. This picture shows what is called "Christian Youth" marching for an out-door meeting - probably in the late 1930's. Not all the participants look specially young, but they are correctly marching - under the slogan "The Norwegian People for Christ" (Repro: Arthur Sand, Oslo)

societies were organisations, was a modern phenomenon. So was the fact that they were founded by non-experts, laymen and laywomen as opposed to the ministers and formally educated religious experts. But at the same time they settled in local societies, and were restrictive as to the participation of women preachers, and this made clear that the organisations also referred to premodern values and standards. ${ }^{3}$

\section{THE NORWEGIAN HOME MISSION OF THE 1850’s}

This rather strange combination of modern and premodern elements also in several ways was decisive when the leaders of the Norwegian home mission, the Luther Foundation, formulated their views on contemporary society and the aims of

${ }^{3}$ A recent and very broad investigation on the religious movements in Norway c. $1780-1920$ is FURSETH 1999. 


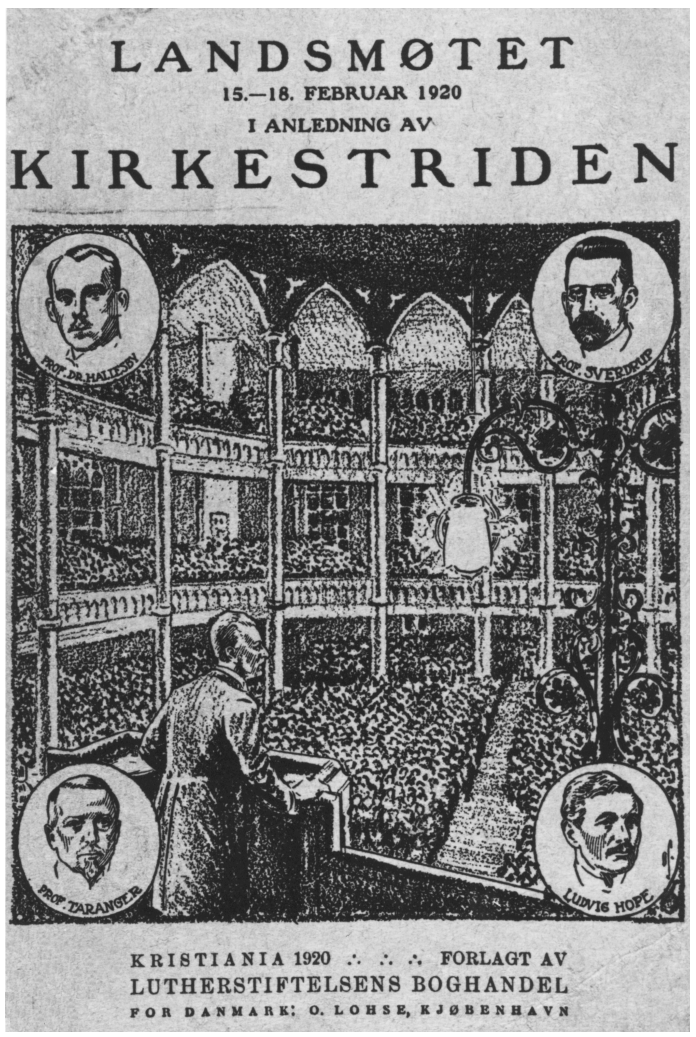

Fig 2. This is actually the cover of the book presenting the official reports from the important meeting in 1920, when Ole Hallesby was among the spokesmen for a non-cooperation policy against the liberal among the Norwegian clergy. The picture shows the dimensions of the meeting. Hallesby's portrait is in the upper left corner (Repro: Arthur Sand, Oslo)

the inner mission as such. The explicit argument put in favour of establishing a formal home mission organisation was that a religious crisis had developed. During the 1850 's and 1860 's, Norway was dominated by several religious revivals, and it was the leaders of these revivals who actually became the leaders of the new organisation. But what was the content of this alleged religious crisis? It seems that many of the religious leaders thought that the effect of the growing Norwegian industrialism, capitalism and migration was that the moral and religious standards of the old society were seriously threatened. The obedience to God, to the Ten Commandments, to the authority of the Bible, so established in previous times, no longer was a commonly accepted fact in society. And why was that so? The spokesmen of the early home mission argued that one main point simply was that modern people did not accept authority as such, they wanted to decide for themselves, to make more money, have better lives and personal freedom. This was the cultural and social content of the postulated religious crisis. And how could this crisis be overcome 
according to this critical religious view? The assumption of the inner mission leaders was that a crisis like this only could be neutralized by using the weapons of the modern society itself. One had to use modern media like newspapers and public discussions, it was necessary to organise the Inner Mission activities, and to do it just like the expanding workers and burghers did when they expanded or sought to have support in favour of their demands and interests. The problem was, of course, that the use of modern strategies in order to establish the moral and religious codes of the premodern society could easily turn out to be both ambiguous and arbitrary. This was fully understood by the Norwegian home mission leaders of the 1850's and 1860 's, and they tried to establish their society as some sort of an ad interim organisation. We need this organisation just now, they said, but it is not meant as any kind of a permanent structure. Let us use The Luther Foundation, the inner mission society as an instrument for distributing bibles and new testaments, let us also use it for administration of lay preachers all around the country, for collecting money and for controlling and centralizing public discussion - as long as it is needed. But when we have reached our aims and the Norwegian people has once again returned to the old standards of moral and religion, this organisation actually will no longer be needed.

Of course, neither as a strategy nor as an ideology this was acceptable and realistic. But I find it very interesting as a starting point for the organisation: The organised Norwegian inner mission was from its beginning in the 1850's and 1860's identified by what one perhaps might call an intrinsic ambivalence: It was aiming at reestablishing old, premodern values by using modern strategies, and was left with some kind of a scepticism towards its own methods.

\section{A REORGANISED SOCIETY IN 1891}

The Norwegian society changed dramatically during the second half of the 19th century. ${ }^{4}$ Industrialism, capitalism and migration had come to stay. The cities were rapidly growing, the social differences between the classes became more clear, and political conflicts threatened the stability of the society. In 1884, parliamentarism was introduced as the only way of stabilising the growing political conflicts. As seen by the home mission leaders, however, the religious crisis became more of a permanent crisis than could have been foreseen twenty years earlier. So, in 1891, the $\mathrm{Lu}$ ther Foundation was reorganised and made a permanent, modern, nationwide organisation under the name of The Norwegian Home Mission Society and with the aim of making Norway a Christian society. The instruments of this reorganised society were as follows: A national network of professional lay preachers was established, and the new organisation was installed with three levels - the central committee in the capital, the regional boards, and the local boards. The fundament of the whole organisation, however, still was the local assemblies of what usually was called "the

\footnotetext{
${ }^{4}$ A survey on 19th century Norway could be found in HUBBARD et al. 1995, esp. Chs. 6-7.
} 
friends" or "the spiritual friends". These small groups were formally organised, and many of them built their own houses, usually called "houses of prayer" (in Norwegian: "bedehus"), where the meetings and assemblies of the friends were situated two, three or more days of the week.

And the work went on. There were quite a few revivals on local, regional and national level, but the Norwegian society kept changing. Even more people moved to the cities, the religious movements did not grow as fast as planned, while other popular movements expanded - both socialists, unions and teetotalists established themselves as central political forces.

\section{A NEW GENERATION OF HOME MISSION LEADERS}

In this situation a new generation of leaders took over the Home Mission Society. Both were theologians, and one of them was also a minister. In 1912, the minister Johan Martin Wisløff (1873-1944) was appointed secretary general, or executing leader of the organisation, while dr. Ole Hallesby (1879-1961), professor of theology at the recently (1907) established Free Faculty of Theology in Oslo, was appointed head of the board. In cooperation, the two new leaders immediately started to point out new directions for the organisation.

In a series of articles in the Home Mission's periodical, professor Hallesby during the autumn of 1912 made some main statements of his policy. We have one central aim, he declared, and that is to rechristianize whole Norway. Secularisation, atheism, godless propaganda and modern heathendom are all threatening to make our country a new spiritual wilderness, and our people a people without culture and values. In a situation like this we cannot just sit down and observe or regret what is happening; we have to act, and act according to an explicit and conscious strategy. What is, then, the hope of Norway? How is Norway to be rechristianized? Our aims can only be achieved by means of a total renewal, a national revival. And how could a national revival be organized? Professor Hallesby here launched a slogan that was to be heard for several years to come, at that was: "Fill the institutions!" By this, he meant that the best way to open up for a national revival, a full rechristianization of the Norwegian society, was to place severe Christian believers in central positions all over the society.

But this was not all. Professor Hallesby also thought that the Home Mission had to show the way, by establishing its own institutions, especially schools, for young people, for teachers, for lay preachers, for craftsmen, for farmers. Furthermore, Hallesby suggested that the new times were in need of Christian hospitals, charity institutions, educated and full-time lay preachers employed by the Inner Mission and new "houses of prayer" where different kinds of activities could take place. During the following years, the Home Mission spent a lot of money founding and funding these kinds of schools, institutions and houses all over the country. Another point was, according to Hallesby, that the internal strategies had to be refined. The local Home Mission groups, "the friends", had to modernize, to become more effective 


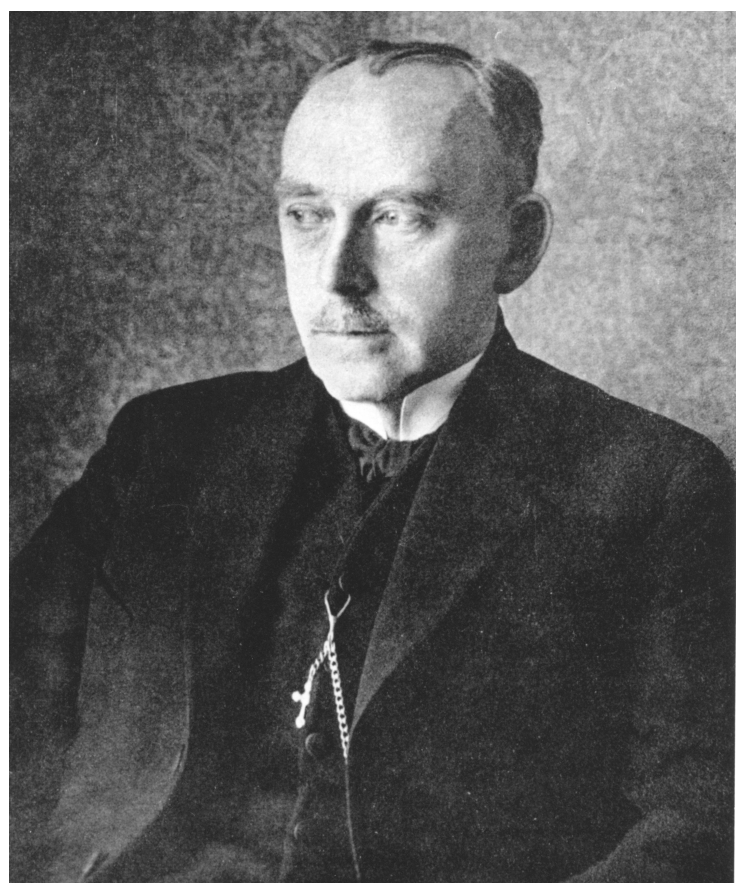

Fig 3. Professor Ole Hallesby in his later years, probably the 1940's or 1950's. Beware of the golden cross hanging on a chain: The cross as sign of victory - and repentance (Repro: Arthur Sand, Oslo)

and expansive. He invited the local "friends" to establish Sunday schools, clubs and choirs for young boys and girls, family groups for the young, Christian couples and so on. Within a few years, the Home Mission organisation had become highly differentiated both on central and on local level.

This very expansive strategy was in fact not stopped until the Second World War. And the success was remarkable and astonishing. There is no doubt that the Inner Mission became a vital and central cultural, social and political power in the Norwegian society, a position clearly demonstrated by the rebuilding of its headquarters in the Norwegian Capital. In the 1930's, the Home Mission built a modern complex of hotel, offices, administration centre and assembly hall close to the Royal Castle in Oslo.

\section{POLITICAL AIMS WITHOUT POLITICS?}

How is this to be characterized, this far? Beyond doubt, the new Inner Mission strategy conceived by professor Ole Hallesby represented a further modernization not only of the organisation but of the strategical thinking. Provoked and threatened by the emerging political and moral popular organisations of socialist and teetotalist 
origin, and obviously inspired by their effectivity and success, the Home Mission leaders both wanted to stand up against these godless tendencies and tried to imitate their strategy and ways of working. While the socialist organisations tried to take over the established social organisations and to win national and local elections, Hallesby tried to establish alternative, Christian institutions. Only by publicly demonstrating that the Home Mission organisation was capable of competing with rivalizing, non-Christian organisations, there would be possibilities of the great national awakening or revival to come. Hence, it is not hard to see that Hallesby's strategy was a political strategy and a strategy of competition: The fight was over the souls of all Norwegians, and the fight had to be won by either godless political parties or by a Christian organisation.

It is, however, interesting to observe that professor Hallesby and the home mission leaders very seldom were talking about politics in direct terms. On the contrary, Hallesby most often speaks about politics and politicians in terms of contempt or marginalization. There is, he often says, a safe way to go if one is to destroy the innocence and deeper culture of a people, and that is the way of politics. Politics is conflict, hatred and destruction put into system. On the other hand, Christian faith as expressed through the inner mission ideals - puts together what a degenerated, godless and restless society has taken apart. Christian faith makes the individual free and restores the god-willed institutions in society based on the authority of God's own word. As a consequence, Hallesby is very sceptical about true Christians being politicians or engaging for instance in workers unions. There is, he says, only one important thing in life, and that is the struggle for The Kingdom of God to come, to make the old and well tested values of Christianity accepted as the fundamentals of society - in short: The struggle for full rechristianization, not political parties or higher wages, is the first and only obligation for true Christians.

\section{THE REVIVAL OF IDEOLOGIES}

Hallesby's and the Home Mission's great era, in fact, became the mid-war period, the 1920's and 1930's. This was a period, even in Norway, of extensive political rhetoric. It is, then, very tempting to underline only this dimension of what was said and what was done. Indirectly, the Inner Mission made puritan and pietist Christian culture a question of political alternatives or exclusive choices, and - for instance - created effective barriers between religion and socialism, or a rather negative attitude among Home Mission members to political activity. And further, it is quite easy to understand why the Home Mission strategy had to turn problematical: It was - after all - not linked to distinct and common social or cultural values that could be accepted by others than the Home Mission's own members. Therefore, the rechristianization rhetoric created a dividing line between believers and nonbelievers. Only Home Mission members themselves dreamed about The Great National Awakening; to others, this awakening seemed the purest night-mare. Second, compared with for instance the Socialist Party, the workers' unions or the 
Teetotalist Movement, the Inner Mission Society was of limited force both economically, socially and rhetorically. The public competition - if there ever was one at all was between David and Goliat, and the point here is that David might have had a just case and all heavens blessings, but he still was the youngster and Goliat stayed a giant.

\section{- OR THE IDEOLOGY OF REVIVALS?}

But this is not all. Until this point, I have mostly been concerned with leadership, public strategy, official rhetoric and direct political implications of the work of the Inner Mission and professor Hallesby in the 1920's. But since this is a Conference on ethnology of religion, there should of course also be a question of culture and people here. Professor Hallesby was not the only member of the Home Mission, although he was conceived as - and indeed he understood himself as - the eloquent and undisputed leader and chief of the organisation. Hallesby, however, was in many ways a wise and experienced man. Since early in the century, he had himself been travelling as a lay preacher (he was in fact never ordained as a minister), hoping for revival and awakening. He knew his supporters, and he was a very intelligent interpreter of their culture and ways of thinking. In a very interesting book from 1928 published as a celebration of the Inner Mission's 60th anniversary - professor Hallesby addresses the ordinary members of his organisation. The book is called From the Working Fields. A Few Words to the Friends of the Inner Mission. ${ }^{5}$

Of course, Hallesby has to make statements of his ambitious strategy here, too. But in a strange way, these ambitions seem to fade away, and instead, he starts to talk about the individual soul, the local communities of "spiritual friends" - without money, with no eloquence or strong organisation, left only with confusion, despair, and a small hope of the grace of God. The book as such is less a selfsufficient presentation of the rechristianization program than a modest and sympathetic sermon to troubled individuals. ${ }^{6}$

What "the friends" actually long for, Hallesby says, is not necessarily obvious success or external accept, but a local revival and a warm, friendly acceptance at the local "house of prayers". And he gives lengthy descriptions not only of how nice and fruitful these close and warm religious communities could be, but also of the simple and severe religious communities of former days, at the countryside, when the premodern innocence still dominated people's bodies and minds. ${ }^{7}$ The warmth of the friends and the fire of the revival is also the fire and the warmth of the past. Why do we need all these organisations, educated preachers and effective administrators? Hallesby asks. In fact, he continues, the strength and the center of genuine religious

\footnotetext{
5 The Norwegian title of the book is Fra arbeidsmarken. Et ord til indremissionsvenner.

${ }^{6}$ It is possible to get at least a certain impression of Hallesby's way of thinking on these matters through some of his translated books, e.g. HALLESBY 1934 and HALLESBY 1996.

7 On central traits in 19th century conservative Norwegian pietism, cf. AMUNDSEN 1997 (a).
} 


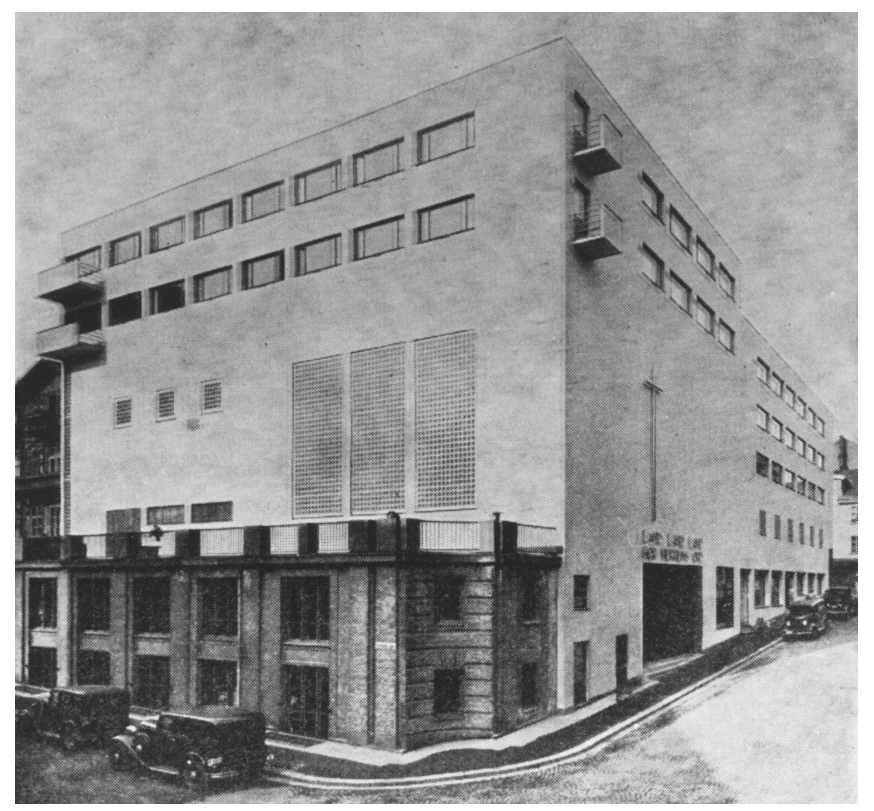

Fig 4. The headquarters of the Norwegian Inner Mission Society as it was presented after a major rebuilding in 1935 - in the center of the Norwegian capital, Oslo (Repro: Arthur Sand, Oslo)

life is the local community of friends. If this community is well-functioning, pure and without conflicts, a mild and quiet revival will come. How it starts, will be unknown to us, and whereto it will take us, is impossible to guess, Hallesby further says. In these passages, Hallesby's rhetoric is of another kind than in the public speeches and debates. Actually, it almost seems as if the "friend"-rhetoric is contra-factual to the modernized "Great-National-Awakening"-rhetoric. The "friend"-rhetoric is both nostalgic and, partly pre-modern, but it is hardly occupied with the new movement strategy at all. ${ }^{8}$

\section{THE PROBLEM OF THE 'REMOVED CANDLESTICK'}

And there is even more to it. Having placed the centre of all religious life in Norway among the local group of friends, who actually needed no organisation to experience revival, Hallesby goes even further. Why does this quiet, serious, local awakening still not appear? he asks his readers. Is it perhaps because you have not repented - every one of you? Does the community of friends, the "house of prayer", house hidden sins? In this central passage he is kind enough to quote a very impor-

${ }^{8}$ On the nostalgic character of the Church's view on its own history, cf. AMUNDSEN 1997 (b). 
tant verse from the New Testament, a verse that belongs to the central topoi in the revivalist culture, i.e. The Book of Revelation, chapter 2, verse 5: "Remember therefore from whence thou art fallen, and repent, and do the first works; or else I will come unto thee quickly, and will remove thy candlestick out of this place, except you repent."

This, I think, is the ultimate, inner box, the rhetoric of the rhetoric in the inner mission culture. Still in the process of building up an effective and powerful religious organisation, professor Hallesby also reveals the weakest - and perhaps also the most sympathetic - element of this culture: its almost immense introspection and individualism.

As seen from outside, this is the weakest point of the whole project in the 1920's and 1930's: not the lack of funds, members or political support, but the religious ideology itself. What Hallesby actually was saying - and I think that this was a point shared by most of his home mission "friends" - was that there will be no rechristianization, no common success, no Great National Awakening - unless every one of you show up a clean heart, a pure mind, a warm hand. Inner Mission may not need formal organisation or educated preachers, but it cannot do without every single "friend" - "repenting, and doing the first works". If there were no "friends" with these genuine qualities, God himself may "remove the candlestick from this place". Perhaps Norway was condemned? Perhaps the darkness of godlessness, politics and conflicts was the actual future - because of the "friends" themselves?

\section{THE IRONY OF THE 'SECULARIZED CANDLESTICK'}

If I am right in interpreting professor Ole Hallesby like this - and, in fact, I think I am right here - I would like to point out that this is a conclusion of a certain relevance to the main theme of this Conference, "Politics and Folk Religion".

I have tried briefly to describe the historical and rhetorical conditions and traditions in a specific European country in the inter-war period. It was a period when in many countries political and religious movements were in serious conflict over social values, political power and control of public institutions. In a Lutheran and even pietist tradition as the Norwegian, there seem to have been made strong efforts to make local, popular religion a fundament for strong revival movements aiming at taking spiritual control over the whole country. In one perspective, professor Ole Hallesby is a significant case here. Local pietism and communities of "friends" were parts of a strong popular religiosity almost all over Norway at the time, and Hallesby and the Home Mission leaders tried to make them stand up against socialism, political conflicts and godlessness.

On the other hand, there are central elements in the very pietistic and revivalistic ideology that make such political and cultural efforts difficult to sustain. Pietism is, indeed, expansive and authoritarian, but it is also extremely individualistic and self-critical. Professor Ole Hallesby was well aware of this, and he explicates it quite clearly in dialogue with all his inner mission "friends". Thus, he also openly shows 
that pietistic strategies for rechristianization in a pluralistic community have to fail, at least when compared with uni-linear, power-seeking movements of a more distinct secular origin. While the pietistic "spiritual friends" of the 20th century always have feared that "the candlestick" might be taken away from them, the secular, political movements have grasped the "candlestick" and taken it to their place.

\section{LITERATURE 9}

AMUNDSEN, Arne Bugge

1992: “'Vekkelsens ansikter' - Fra bedehus- og foreningsmiljø i mellomkrigstidens Rakkestad", Borgarsyssel Museum. Arbok nr. 3 1985-90, Sarpsborg, 72-122.

1997a: "'The Living Must Follow the Dead'. In Search of 'The Religious Person' in the Nineteenth Century", Arv. Nordic Yearbook of Folklore 1997, vol. 53, Uppsala, 107-130.

1997b: “'The Haugean Heritage' - a Symbol of National History”, Jens BRAARVIG/Thomas KROGH (eds.): In Search of Symbols. An Explorative Study, (Occasional Papers from the Department of Cultural Studies, University of Oslo 1), Oslo, 214-233.

Die Kirche von Norwegen. (Ekklesia. Eine Sammlung von Selbstdarstellungen der christlichen Kirchen II, herausgegeben von Friedr. SIEGMUND-SCHULTZE), Leipzig 1936.

FURSETH, Inger

1999: People, Faith and Transition. A Study of Social and Religious Movements in Norway, 1780s-1905. (Dr. polit. Thesis, University of Oslo), Oslo.

GJESSING, Marcus

1911: Norwegische Kirchenkunde. (Kirchenkunde des evangelischen Auslandes II), Giessen.

HALLESBY, Ole

1934: The Christian Life in the Light of the Cross, Minneapolis, Minnesota.

1996: Unsere Kraft wächst aus der Stille. Lektionen eines Lebens mit Jesus. (R. Brockhaus Taschenbuch 361), Wuppertal.

HASSING, Arne

1980: Religion and Power. The Case of Methodism in Norwegian History, Wainesville, North Carolina.

HuBBARD, William H. et al. (eds.)

1995: Making of a Historical Culture. Historiography in Norway, Oslo/Copenhagen/Stockholm/Boston.

MOLLAND, Einar

1957: Church Life in Norway 1800-1950, Minneapolis, Minnesota.

OFTESTAD, Bernt T.

1980: "Lekmannsprekenens kirkelige legitimitet. Fra debatten om den 'offentlige' lekmannspreken innen norsk kirkeliv i forrige århundre”, Tidsskrift for Teologi og Kirke 51, Oslo, 189-206.

1983: "Folkekirken i pietistisk vekkelsesteologi. O. Hallesbys og Ludvig Hopes vurdering av folkekirken", Folkkyrkoteologi och folkkyrkotradition $i$ Norden under 1900-talet, Lund, 42-57.

1986: “Ole Hallesby og Ludvig Hope som kirkelige strateger”, Kirke og Kultur 91, Oslo, 215-229.

1998: Den norske statsreligionen - fra фvrighetskirke til demokratisk statskirke, Oslo.

OFTESTAD, Bernt T.-RASMUSSEN, Tarald-SCHUMACHER, Jan

1991: Norsk kirkehistorie, Oslo.

OUSLAND, Godvin

1982: Gullaldertid. Vekkelsesretninger i Norge 1900-1940. Hva de laerte og siktet på, Oslo.

REPSTAD, Pål (ed.)

1996: Religion and Modernity - Modes of Co-existence, Oslo.

RUDVIN, Ola

1962: "Indremisjonshøvdingen", Ole Hallesby. En høvding i Guds rike, Oslo, 89-97.

1970: Indremisjonsselskapets historie II, Oslo.

${ }^{9}$ In the footnotes, I have only referred to literature that might be read in English or German. The bibliography, on the other hand, refers to books and articles that I have actually used. 
SVERDRUP, Edvard

1918: Fra Norges kristenliv. Den norske Lutherstiftelse og Det norske lutherske Indremissionsselskab 1868-1918, Kristiania.

THORKILDSEN, Dag

1996: "Church and Nation in the 19th Century. The Case of Norway", Ingmar BRoHED (ed.): Church and People in Britain and Scandinavia. (Bibliotheca historico-ecclesiastica lundensis 36), Lund, 249-266. 